\title{
Suppressive Effects of Various Amino Acids against Ouabain-Induced Seizures in Rats
}

\author{
Y. TSUKADA, N. INOUE, J. DONALDSON, and A. BARBEAU
}

\begin{abstract}
SUMMARY: The suppressive effect of various amino acids against ouabaininduced seizures was investigated in young female rats. The amino acids were injected into the left lateral ventricle 10 minutes prior to the intraventricular administration of $5 \mu \mathrm{g}$. of ouabain. Animals receiving $1.9 \times 10^{-1} \mathrm{M}$ solutions of hypotaurine and of $\beta$ alanine were almost completely protected from the ouabain seizures. Administration of L-alanine and of glycine was also effective, although running and leaping seizures still occurred to some extent. Betaine reduced only clonic-tonic and whole body flexion and extension seizures. In contrast, L-proline exclusively suppressed clonic-tonic and focal clonic seizures. Rats injected with ise-
\end{abstract}

RÉSUMÉ: Nous avons étudié l'effet suppresseur de plusieurs acides aminés contre les convulsions induites par la ouabaine chez la jeune rate. Les acides aminés furent injectés dans le ventricule latéral gauche 10 minutes avant l'administration intraventriculaire de $5 \mu \mathrm{g}$. de ouabaine. Les animaux recevant des solutions de concentration $1.9 \times 10^{-1} \mathrm{M}$ d'hypotaurine et de $\beta$-alanine étaient presque complètement protégés contre les convulsions induites. L'administration de L-alanine et de glycine était également efficace, même si les décharges cursives et les sauts étaient encore présents. La betaine ne réduisait que les convulsions tonico-cloniques ou celles se manifestant par une flexion et une extension du corps. Par contraste, la L-proline supprimait exclusivement les convulsions tonico-cloniques ou purement cloniques localisées. Les rates thionic acid showed increases in incidence of running and leaping seizures while L-arginine in high concentrations caused aggravation in clonic-tonic seizures. L-cysteine, even in low concentrations, also brought about an increase in the occurrence and incidence of clonic-tonic seizures. The $E D_{50}$ of hypotaurine was $10.11 \times 10^{-2} \mathrm{M}$ for running seizures and $4.63 \times 10^{-2} M$ for clonictonic seizures; that of $\beta$-alanine was $14.01 \times 10^{-2} M$ for running seizures and $5.50 \times 10^{-2} \mathrm{M}$ for clonic-tonic seizures. However, hypotaurine and $\beta$-alanine, the most effective compounds tested in the present studies, provided less protection than taurine previously examined by us under similar conditions (Izumi et al., 1973).

ayant reçu l'acide isethionique montrèrent ure augmentation de l'incidence des convulsions cursives et des sauts. La L-arginine, en forte concentration, aggravait les convulsion tonicocloniques. Il en fut également ainsi pour la L-cysteine, même en faibles concentrations. La $D E_{50}$ de l'hypotaurine est de $10.11 \times 10^{-2} \mathrm{M}$ pour les convulsions cursives et de $4.63 \times 10^{-2} \mathrm{M}$ pour les convulsions tonico-cloniques; celles de la $\beta$-alanine sont de $14.01 \times 10^{-2} \mathrm{M}$ et de $5.50 \times 10^{-2} M$, respectivement. Cependant il faut noter que l'hypotaurine et la $\beta$-alanine, les composés les plus efficaces dans la présente étude, offrent tous deux une protection moindre contre les convulsions induites par la ouabaine que la taurine que nous avions préalablement étudié en détail (Izumi et al., 1973).

Department of Neurobiology, Clinical Research Institute of Montreal, 110 Pine Avenue West, Montreal, Quebec, Canada.

Reprint address: Dr. André Barbeau, Clinical Research Institute of Montreal, 110 Pine Avenue West, Montreal, Quebec, Canada H2W 1 R7.

\section{INTRODUCTION}

Recent investigations on the biochemistry of convulsive seizures have revealed the existence of abnormalities in the metabolism or brain content of various amino acids. For example, an accumulation of alanine and decreased citrate levels were observed in the preconvulsive stage; on the other hand, GABA increased in rat brain during tonic seizures as well as during post-convulsive stages (Nahorski et al, 1970). According to some authors, electroconvulsive shocks markedly inhibit the conversion of ${ }^{14} \mathrm{C}$-glucose to amino acids and the incorporation of ${ }^{14} \mathrm{C}$ into proteins in mouse brain (Dunn and Giudetta, 1971) and in rat neocortical slices (Jones and McIlwain, 1971). These findings were challenged by others (Barkulis et al., 1960; Orrego and Lipmann, 1967). Recently, van Gelder et al. (1972) reported lower levels of GABA and aspartic acid in all regions of epileptic human cortex sampled and lower concentrations of glutamic acid and taurine together with very high glycine levels in human cortical epileptic foci. Koyama (1972) observed similar decreased concentrations of taurine, glutamate, asparate and GABA during the period preceding cobalt induced convulsions in cats. However, Reynolds and Gallagher (1973) found neither changes in amino acid levels nor alterations of $\mathrm{U}^{14} \mathrm{C}$-glucose incorporation into amino acids during any of the stages of the seizure induced by Flurothyl.

Some amino acids have been shown to be neurotransmitter candidates with inhibitory or excitatory functions. Micro-electrophoretic techniques to substantiate this 
nypothesis were reviewed by Curtis and Crawford (1969). Uptake studies have been carried out in central nervous system tissue or retina (Balcar and Johnston, 1973; Ehinger, 1972; Kaczmarek and Davison, 1972; Snyder, Young et al., 1973; Snyder, Yamamura et al., 1973).

Finally, some authors have approached the problem with the help of autoradiography (Ehinger and Falek, 1971; Iversen and Schon, 1973). These investigations concluded that $\gamma$-aminobutyric acid (GABA), glycine, $\beta$-alanine and taurine may be inhibitory neurotransmitters, while glutamic acid and aspartic acid have excitatory functions.

On the other hand, once recommended trials of treatment with amino acids in human epilepsy no longer appear useful today, except possibly with gamma-amino-betahydroxybutyric acid (GABOB) (Hahashi, 1972). Recently, however, some antiseizure effects of taurine have been reported (Barbeau and Donaldson, 1974; Izumi et al, 1973; van Gelder, 1972). van Gelder (1972) first demonstrated the suppressive effect of taurine administered systemically against cobalt-induced seizures in cat and mouse. Izumi et al. (1973) then found that the intraventricular injection of taurine revealed more marked antiseizure effects than GABA against ouabaininduced seizures in rats. Moreover, Barbeau and Donaldson (1974) reported that taurine also possessed anticonvulsant activity against certain types of human epilepsy.

The present studies were carried out to investigate the activity against ouabain-induced seizures in rats of various amino acids, including some precursors, a metabolite and various structural analogues of taurine in order to delineate the specificity of this amino acid.

\section{MATERIALS AND METHODS}

Female Sprague-Dawley rats weighing approximately $180 \mathrm{~g}$. were implanted with a cannula into the left lateral ventricle as described previously (Donaldson et al., 1971). A volume of $50 \mu \mathrm{l}$. was used for the administration of amino acid and ouabain solutions which were injected through the cannula at a rate of $25 \mu \mathrm{l} . / \mathrm{min}$. Two different doses of each amino acid $\left(9.5 \times 10^{-2} \mathrm{M}\right.$ or 1.9 $\left.\times 10^{-1} \mathrm{M}\right)$ were administered $10 \mathrm{mi}-$ nutes prior to the injection of $5 \mu \mathrm{g}$. in $50 \mu \mathrm{l}$. ouabain. Moreover, various concentrations of hypotaurine and $\hat{\beta}$-alanine were used to investigate median effective doses (EDs0) for running and clonic-tonic seizures. The control animals received an injection volume of $50 \mathrm{l}$. of buffered saline. The effects of amino acids against the different types of ouabain-induced seizures previously described in rats (Izumi et al., 1973) were observed for fifteen minutes after the administration of ouabain.

\section{Preparation of solutions}

Ouabain solutions were prepared at a concentration of $5 \mu \mathrm{g} . / 50 \mu \mathrm{l}$. in warm $0.85 \%$ saline. The amino acids were dissolved in a $\mathrm{NaCl}$ solution containing $5 \mathrm{mM}$ phosphate buffer, to obtain an osmotic pressure of 290 to 300 mosm. and the solutions were checked by osmometry. The $\mathrm{pH}$ of the amino acid solutions was adjusted to 7.0-7.2. The control solution contained $5 \mathrm{mM}$. phosphate buffer in a $\mathrm{NaCl}$ solution.

Ouabain, betaine and isethionic acid were purchased from Sigma Chemical Co., glycine, L-alanine and L-arginine from California Biochemical Research, hypotaurine and L-cysteine from Calbiochem, L-proline from Nutritional Biochemical Corporation and $\beta$-alanine from Eastman Kodak Co.

\section{STATISTICS}

Median effective doses (EDso \pm 95\% confidence limits) of hypotaurine and $\beta$-alanine against clonic-tonic and running seizures were obtained by the graphic method of Litchfield and Wilcoxon (1949). Statistical analysis for differences in seizure occurrence between control and test groups was carried out by the "difference between proportions of two small samples method" (Winer, 1971). Student's t-test (Goldstein, 1964) was applied to analysis of differences between control and test groups in compari- sons of seizure incidence and of latency in onset of the first seizure.

\section{RESULTS}

Occurrence and incidence

Pretreatment of the animals with hypotaurine (the main precursor of taurine), $\beta$-alanine, L-alanine and glycine caused a dose dependent decrease in seizure occurrence and incidence (Tables 1 and 2). Test rats receiving hypotaurine at 10 minutes prior to the ouabain injection were kept free from all seizure activities at high concentrations $\left(1.9 \times 10^{-1} \mathrm{M}\right)$. Moreover, even in low concentrations $\left(9.5 \times 10^{-2} \mathrm{M}\right)$, the compound completely suppressed clonic-tonic, whole body flexion and extension seizures (WBFE), and to a lesser extent, focal clonic seizures. This concentration of hypotaurine also decreased the incidence of running and leaping seizures.

Intraventricular administration of $1.9 \times 10^{1} \mathrm{M} \beta$-alanine showed significant protective effects against all types of ouabain-induced seizures. At low concentrations $\left(9.5 \times 10^{-2} \mathrm{M}\right)$ the compound completely abolished focal clonic and WBFE seizures and significantly decreased clonic-tonic seizures.

Animals injected with high concentrations of either L-alanine or glycine were protected from WBFE, clonic-tonic and focal clonic seizures and to a lesser extent from running and leaping seizures. Low concentrations of these two amino acids also completely suppressed WBFE and clonic-tonic seizures. Furthermore, glycine had some suppressive effect against leaping and running seizures at a low concentration. Administration of $9.5 \times 10^{-2} \mathrm{M}$ or $1.9 \times 10^{-1} \mathrm{M}$ betaine protected rats from WBFE and clonic-tonic seizures only. High doses of L-proline intensified running seizures but clonic-tonic seizures were decreased in incidence. Isethionic acid $\left(9.5 \times 10^{-2} \mathrm{M}\right)$ showed no significant protective action.

At the other end of the spectrum, the animals receiving $50 \mu 1$. of $1.5 \mathrm{x}$ 10-1 M L-arginine had some enhancement of clonic-tonic seizures. Similarly intraventricular injections of L-cysteine markedly increased 
TABLE 1-1

Suppressive Effects of Amino Acids against Ouabain-Induced Seizures: Occurrence (1)

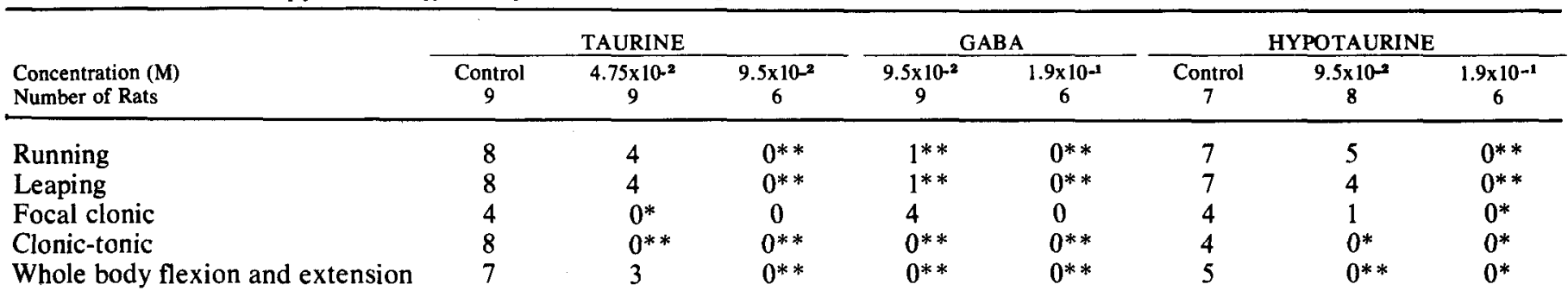

Occurrence: Number of rats showing each type of seizures

Differences between control and test animals indicated by $* * P<0.01$ and $* P<0.05$.

Data on taurine and GABA were quoted from the study by Izumi et al. (1973) $\left(9.5 \times 10^{-3} \mathrm{M}\right.$ L-leucine was used as a control for taurine and GABA in that study).

TABLE 1-2

Suppressive Effects of Amino Acids against Ouabain-Induced Seizures: Occurrence (2)

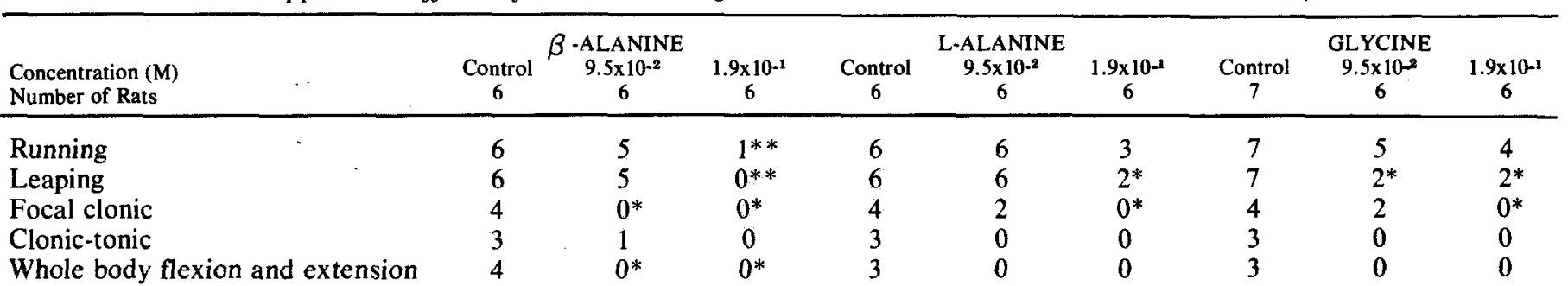

Occurrence: Number of rats showing each type of seizures.

Differences between control and test animals indicated by $* * \mathrm{P}<0.01$ and $* \mathrm{P}<0.05$.

Data on taurine and GABA were quoted from the study by Izumi et al. (1973) $\left(9.5 \times 10^{-3} \mathrm{M}\right.$ L-leucine was used as a control for taurine and GABA in that study).

TABLE 1-3

Suppressive Effects of Amino Acids against Ouabain-Induced Seizures: Occurrence (3)

\begin{tabular}{|c|c|c|c|c|c|c|c|c|c|}
\hline \multirow[b]{2}{*}{$\begin{array}{l}\text { Concentration (M) } \\
\text { Number of Rats }\end{array}$} & \multicolumn{3}{|c|}{ BETAINE } & \multicolumn{3}{|c|}{ L-PROLINE } & \multicolumn{3}{|c|}{ L-ARGININE } \\
\hline & $\begin{array}{c}\text { Control } \\
6\end{array}$ & $\begin{array}{c}9.5 \times 10^{-2} \\
6\end{array}$ & $\begin{array}{c}1.9 \times 10^{-1} \\
6\end{array}$ & $\begin{array}{c}\text { Control } \\
6\end{array}$ & $\begin{array}{c}9.5 \times 10^{-2} \\
6\end{array}$ & $\begin{array}{c}1.9 \times 10^{-1} \\
6\end{array}$ & $\begin{array}{c}\text { Control } \\
6\end{array}$ & $\begin{array}{c}9.5 \times 10^{-2} \\
6\end{array}$ & $\begin{array}{c}1.5 \times 10.1 \\
6\end{array}$ \\
\hline Running & 6 & 6 & 6 & 6 & 6 & 6 & 6 & 6 & 6 \\
\hline Leaping & 6 & 6 & 5 & 6 & 6 & 6 & 6 & 5 & 6 \\
\hline Focal clonic & 3 & 2 & 2 & 4 & 3 & 1 & 5 & 4 & 3 \\
\hline Clonic-tonic & 3 & 0 & 0 & 3 & 1 & 0 & 3 & 3 & 6 \\
\hline Whole body flexion and extension & 4 & $0 *$ & 1 & 4 & 2 & 3 & 4 & 2 & 1 \\
\hline
\end{tabular}

Occurrence: Number of rats showing each type of seizures

Differences between control and test animals indicated by $* * \mathrm{P}<0.01$ and $* \mathrm{P}<0.05$.

Data on taurine and GABA were quoted from the study by Izumi et al. (1973) $\left(9.5 \times 10^{3} \mathrm{M}\right.$ L-leucine was used as a control for taurine and $\mathrm{GABA}$ in that study).

TABLE 1-4

Suppressive Effects of Amino Acids against Ouabain-Induced Seizures: Occurrence (4)

\begin{tabular}{|c|c|c|c|c|c|}
\hline \multirow[b]{2}{*}{$\begin{array}{r}\text { Concentration (M) } \\
\text { Number of Rats }\end{array}$} & \multicolumn{2}{|c|}{ ISE THIONIC ACID } & \multicolumn{3}{|c|}{ L-CYSTEINE } \\
\hline & $\begin{array}{c}\text { Control } \\
5\end{array}$ & $\begin{array}{c}9.5 \times 10^{-2} \\
5\end{array}$ & $\begin{array}{c}\text { Control } \\
6\end{array}$ & $\begin{array}{c}6.3 \times 10^{.2} \\
6\end{array}$ & $\begin{array}{c}9.5 \times 10^{-2} \\
6\end{array}$ \\
\hline Running & 5 & 5 & 6 & 6 & 6 \\
\hline Leaping & 5 & 5 & 6 & 6 & 5 \\
\hline Focal clonic & 3 & 2 & 3 & 3 & 4 \\
\hline Clonic-tonic & 3 & 3 & 3 & 6 & 6 \\
\hline Whole body flexion and extension & 4 & 5 & 3 & 5 & 4 \\
\hline
\end{tabular}


TABLE 2-1

Suppressive Effects of Amino Acids against Ouabain-Induced Seizures: Incidence(l)

\begin{tabular}{|c|c|c|c|c|c|c|c|c|}
\hline \multirow[b]{2}{*}{$\begin{array}{l}\text { CONCENTRATION (M) } \\
\text { NUMBER OF RATS } \\
\end{array}$} & \multicolumn{3}{|c|}{ TAURINE } & \multicolumn{2}{|c|}{ GABA } & \multicolumn{3}{|c|}{ HYPOTAURINE } \\
\hline & $\begin{array}{c}\text { CONTROL } \\
9 \\
\end{array}$ & $\begin{array}{c}4.75 \times 10^{-2} \\
9\end{array}$ & $\begin{array}{c}9.5 \times 10^{-2} \\
6 \\
\end{array}$ & $\begin{array}{c}9.5 \times 10^{-2} \\
9 \\
\end{array}$ & $\begin{array}{c}1.9 \times 10^{-1} \\
6 \\
\end{array}$ & $\begin{array}{c}\text { CONTROL } \\
7\end{array}$ & $\begin{array}{c}9.5 \times 10.2 \\
8 \\
\end{array}$ & $\begin{array}{c}1.9 \times 10-1 \\
6 \\
\end{array}$ \\
\hline Running & $1.9 \pm 0.4$ & $1.0 \pm 0.4$ & $0 * *$ & $0.1 \pm 0.1^{* *}$ & $0^{* *}$ & $2.1 \pm 0.3$ & $1.0 \pm 0.4^{*}$ & $0^{* *}$ \\
\hline Focal clonic & $1.4 \pm 0.6$ & $0^{*}$ & 0 & $0.8 \pm 0.4$ & 0 & $0.7 \pm 0.3$ & $0.1 \pm 0.1$ & $0^{*}$ \\
\hline Clonic-tonic & $2.9 \pm 0.8$ & $0^{* *}$ & $0 * *$ & $0^{* *}$ & $0^{* *}$ & $0.7 \pm 0.3$ & $0^{*}$ & $0^{*}$ \\
\hline $\begin{array}{l}\text { Whole body flexion } \\
\text { and extension }\end{array}$ & $1.3 \pm 0.3$ & $0.3 \pm 0.2^{*}$ & $0^{* *}$ & $0^{* *}$ & $0^{* *}$ & $0.9 \pm 0.5$ & 0 & 0 \\
\hline
\end{tabular}

Incidence: Number of seizures/animal/observation period (mean \pm S.E.).

Differences between control and test animals indicated by $* * \mathrm{P}<0.01$ and $* \mathrm{P}<0.05\left({ }^{* *}\right)$ means increased incidence, significant to $\mathrm{P}<0.001$.

Data on taurine and GABA were quoted from the study by Izumi et al. (1973) $\left(9.5 \times 10^{-3} \mathrm{M}\right.$ L-leucine was used as a control for taurine and GABA in that study).

\section{TABLE 2-2}

Suppressive Effects of Amino Acids against Ouabain-Induced Seizures: Incidence (2)

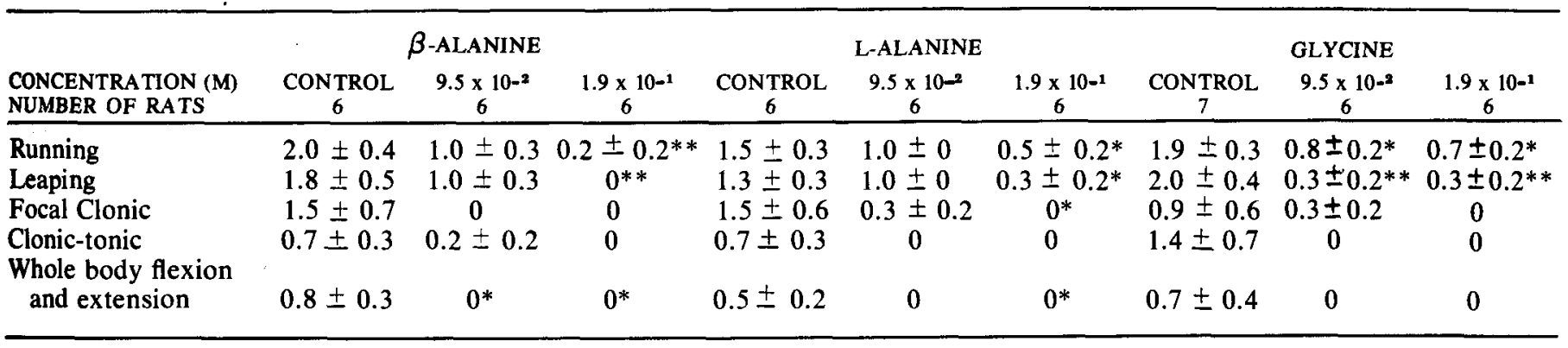

TABLE 2-3

Suppressive Effects of Amino Acids against Ouabain-Induced Seizures: Incidence (3)

\begin{tabular}{|c|c|c|c|c|c|c|c|c|c|}
\hline \multirow[b]{2}{*}{$\begin{array}{l}\text { CONCENTRATION (M) } \\
\text { NUMBER OF RATS } \\
\end{array}$} & \multicolumn{3}{|c|}{ BETAINE } & \multicolumn{3}{|c|}{ L-PROLINE } & \multicolumn{3}{|c|}{ L-ARGININE } \\
\hline & $\begin{array}{c}\text { CONTROL } \\
6 \\
\end{array}$ & $\begin{array}{c}9.5 \times 10^{-2} \\
6 \\
\end{array}$ & $\begin{array}{c}1.9 \times 10^{-1} \\
6\end{array}$ & $\begin{array}{c}\text { CONTROL } \\
\mathbf{6} \\
\end{array}$ & $\begin{array}{c}9.5 \times 10^{-2} \\
6 \\
\end{array}$ & $\begin{array}{c}1.9 \times 10^{-1} \\
6 \\
\end{array}$ & $\begin{array}{c}\text { CONTROL } \\
6 \\
\end{array}$ & $\begin{array}{c}9.5 \times 10^{-2} \\
6\end{array}$ & $\begin{array}{c}1.5 \times 10^{-1} \\
6 \\
\end{array}$ \\
\hline Running & $2.2 \pm 0.8$ & $1.5 \pm 0.3$ & $1.3 \pm 0.3$ & $1.2 \pm 0.2$ & $1.7 \pm 0.2$ & $1.8 \pm 0.2^{*}$ & $1.0 \pm 0$ & $1.0 \pm 0$ & $1.2 \pm 0.1$ \\
\hline Leaping & $2.0 \pm 0.7$ & $1.3 \pm 0.2$ & $1.3 \pm 0.4$ & $1.2 \pm 0.2$ & $1.5 \pm 0.2$ & $1.5 \pm 0.2$ & $1.0 \pm 0$ & $0.8 \pm 0.1$ & $1.2 \pm 0.1$ \\
\hline Focal clonic & $0.8 \pm 0.5$ & $0.3 \pm 0.2$ & $0.3 \pm 0.2$ & $1.0 \pm 0.4$ & $0.5 \pm 0.2$ & $0.5 \pm 0.5$ & $1.0 \pm 0.2$ & $1.2 \pm 0.6$ & $0.7 \pm 0.3$ \\
\hline Clonic-tonic & $0.5 \pm 0.2$ & $0 *$ & $0^{*}$ & $0.5 \pm 0.2$ & $0.2 \pm 0.2$ & $0^{*}$ & $0.5 \pm 0.2$ & $0.5 \pm 0.2$ & $1.8 \pm 0.5^{*}$ \\
\hline $\begin{array}{l}\text { Whole body flexion } \\
\text { and extension }\end{array}$ & $0.8 \pm 0.5$ & 0 & $0.3 \pm 0.2$ & $0.7 \pm 0.3$ & $0.3 \pm 0.2$ & $0.5 \pm 0.2$ & $0.7 \pm 0.3$ & $0.3 \pm 0.2$ & $0.2 \pm 0.1$ \\
\hline
\end{tabular}

TABLE 2-4

Suppressive Effects of Amino Acids against Ouabain-Induced Seizures: Incidence (4)

\begin{tabular}{|c|c|c|c|c|c|}
\hline \multirow[b]{2}{*}{$\begin{array}{l}\text { CONCENTRATION (M) } \\
\text { NUMBER OF RATS } \\
\end{array}$} & \multicolumn{2}{|c|}{ ISETHIONIC ACID } & \multicolumn{3}{|c|}{ L-CYSTEINE } \\
\hline & $\begin{array}{c}\text { CONTROL } \\
5 \\
\end{array}$ & $\begin{array}{c}9.5 \times 10^{-2} \\
5 \\
\end{array}$ & $\begin{array}{c}\text { CONTROL } \\
6 \\
\end{array}$ & $\begin{array}{c}6.3 \times 10^{-2} \\
6 \\
\end{array}$ & $\begin{array}{c}9.5 \times 10^{-2} \\
6 \\
\end{array}$ \\
\hline Running & $1.6 \pm 0.4$ & $2.4 \pm 0.6$ & $1.8 \pm 0.5$ & $1.7 \pm 0.4$ & $1.5 \pm 0.2$ \\
\hline Focal clonic & $1.0 \pm 0.4$ & $0.8 \pm 0.6$ & $0.7 \pm 0.3$ & $1.7 \pm 0.8$ & $2.2 \pm 1.0$ \\
\hline Clonic-tonic & $0.8 \pm, 0.4$ & $0.8 \pm 0.4$ & $0.3 \pm 0.2$ & $5.5 \pm 1.1^{* *}$ & $5.2 \pm 1.4^{* *}$ \\
\hline Whole body flexion and extension & $1.0 \pm 0.5$ & $1.2 \pm 0.5$ & $0.7 \pm 0.3$ & $0.8 \pm 0.2$ & $1.0 \pm 0.5$ \\
\hline
\end{tabular}

Incidence: Number of seizures/animal/observation period (mean \pm S.E.).

Differences between control and test animals indicated by $* * P<0.01$ and $* P<0.05(* *)$ means increased incidence, significant to $\mathrm{P}<0.001$.

Data on taurine and GABA were quoted from the study by Izumi et al. (1973) $\left(9.5 \times 10^{-3} \mathrm{M}\right.$ L-leucine was used as a control for taurine and GABA in that study). 
the incidence of clonic-tonic seizures at the concentrations of $6.3 \mathrm{x}$ $10^{-2} \mathrm{M}$ and $9.5 \times 10^{-2} \mathrm{M}$.

\section{Latency of the first seizure}

Intraventricular administration of hypotaurine, L-alanine, $\beta$-alanine and glycine caused significant dose-dependent increases in the latency of the first seizure between the test (at both $9.5 \times 10^{2} \mathrm{M}$ or $1.9 \times 10^{-1}$ $\mathrm{M})$ and control rats (Fig. 1).
On the other hand, betaine, L-proline, isethionic acid and L-arginine did not exhibit any significant increases in latency, even at the high concentrations. Finally, L-cysteine-treated rats $\left(6.3 \times 10^{-2} \mathrm{M}\right)$ displayed a shorter latency to the first seizure than that of the control animals.

Median effective dose (ED50)

The ED50 (with $95 \%$ confidence limits) of hypotaurine and $\beta$-alanine

\section{LATENCY OF SEIZURE ONSET AFTER VARIOUS AMINO ACIDS}

\section{TIME}

$(\min$.

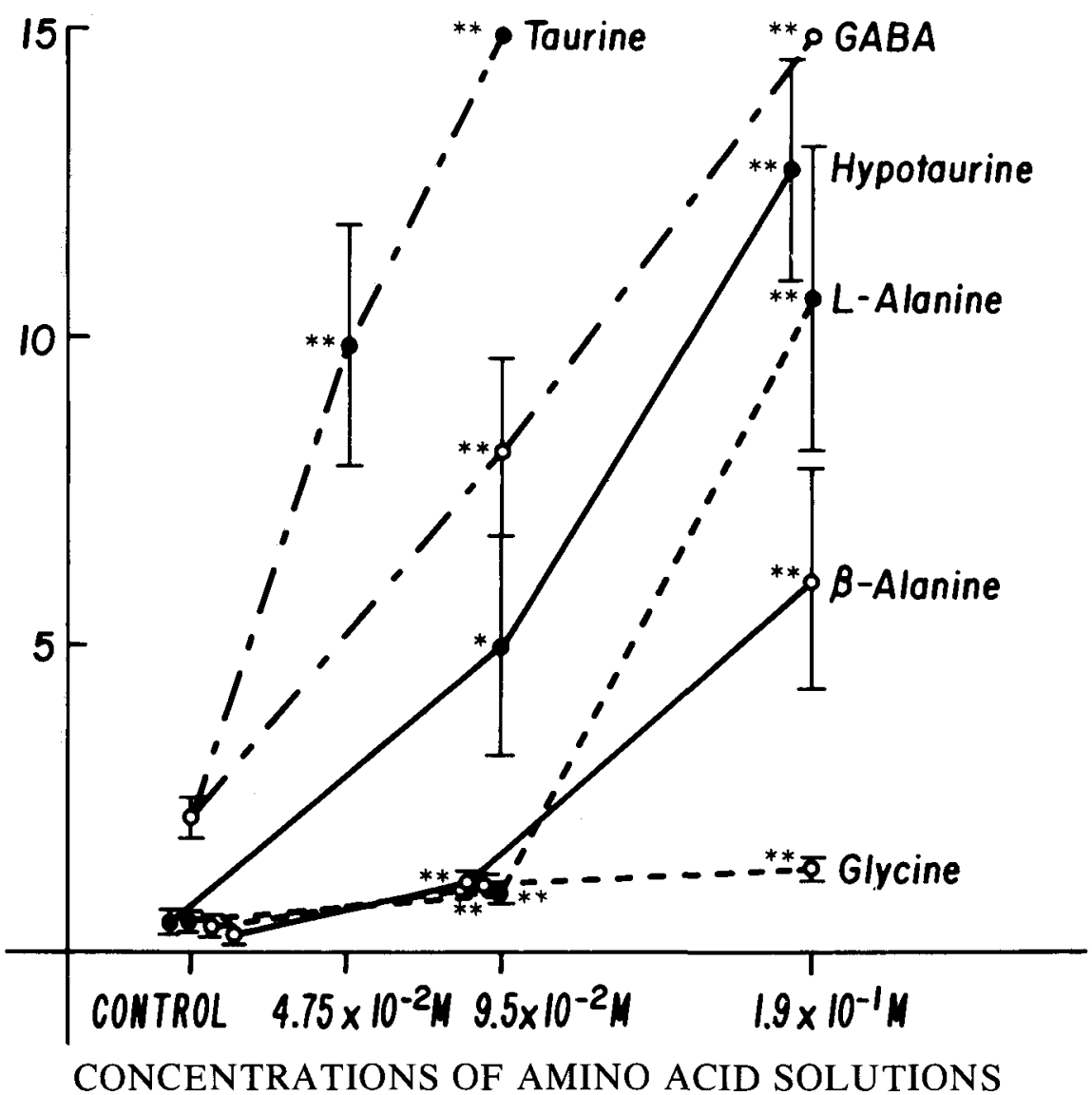

Figure 1-Latency indicated as the time (minutes) between termination of ouabain injection and the first appearance of any seizure activity. When the seizure activity was abolished during the 15 min. observation period, latency was tentatively plotted as $15 \mathrm{~min}$.

Difference between control and two doses of each amino acid indicated by $* * \mathrm{P}<0.01$ and $* \mathrm{P}<0.05$

Isethionic acid, L-arginine, betaine, L-cysteine and L-proline graphically give flat curves below the $1 \mathrm{~min}$. mark and have not been reproduced here. Data of taurine and GABA were quoted from the study by Izumi et al. (1973) $\left(9.5 \times 10^{3} \mathrm{M}\right.$ L-leucine was used as a control for taurine and GABA).

for clonic-tonic and running seizures were obtained by the graphic method (Litchfield and Wilcoxon, 1949). As shown in Table 3, there was a significant difference between the potency of hypotaurine and of $\beta$-alanine against running seizures, but not against clonic-tonic seizures. Furthermore, the potency of hypotaurine was significantly different between running and clonictonic seizures.

\section{DISCUSSION}

Hypotaurine, $\beta$-alanine, L-alanine and glycine displayed stronger and more widely ranged potency against ouabain-induced seizures than any other amino acids tested, except taurine. However, even with the more effective amino acids, running and leaping seizures were apparently more difficult to suppress than other types of seizures.

Hypotaurine, L-cysteine and isethionic acid

Recently, taurine has been shown to have antiseizure activity in human epileptic patients (Barbeau and Donaldson, 1974) and in experimental seizures (Izumi et al., 1973; van Gelder, 1972). Therefore, it was of interest to study the effectiveness of some precursors (hypotaurine and L-cysteine) and metabolites (isethionic acid) of taurine.

Hypotaurine has been identified in adult rat brains (Perry and Hansen, 1973). Oja et al. (1973) reported that no measurable conversion of hypotaurine to taurine occurred in brain homogenates from adult rats although some conversion was found in the brain of 10-year-old rats. These authors suggested that the oxidation of hypotaurine to taurine might be the limiting step in the biosynthesis of taurine in the adult rat brain. If this is true, the suppressive effect of hypotaurine against ouabain-induced seizures may be due to hypotaurine itself rather than to its conversion into taurine. Lähdesmäki and Oja (1973) reported that hypotaurine competitively inhibited the transport of taurine in rat brain slices, while isethionic acid and L-cysteine had no action. This was confirmed by 
TABLE 3

Median Effectice Dose (ED50)

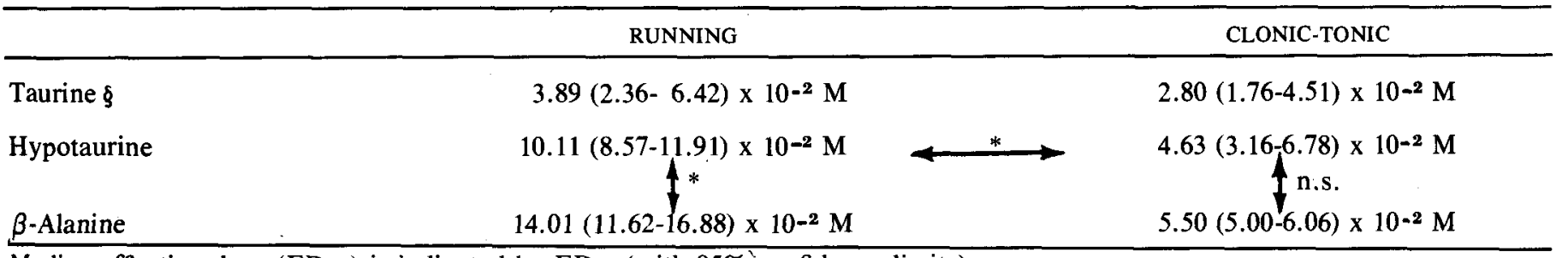

Median effective dose (ED50) is indicated by $\mathrm{ED}_{50}$ (with $95 \%$ confidence limits).

Difference of potency between two substances or between two types of seizures indicated by *: Significant $(\mathrm{P}<0.05)$ and n.s.: not significant.

Differences between taurine and the other two subgroups and between two types of seizures in $\beta$-alanine could not be calculated because of the differences in slope functions in these plotted lines.

EDso for clonic-tonic seizure was calculated at half the value of control occurrence, because the occurrence did not reach $100 \%$ even in control animals.

$\S$ : From the previous study by Izumi et al. (1973).

Kaczmarek and Davison (1972). In the present studies, hypotaurine had marked antiseizure activity while L-cysteine significantly increased the incidence of clonic-tonic seizures.

Cysteine like penicillamine has an $\mathrm{SH}$ group in its structure which more strongly chelates $\mathrm{Ca}^{2+}$ and $\mathrm{Mg}^{2+}$ than EDTA (Boineau, 1973). Cysteine also has the strongest complexes with bivalent ions among numerous amino acids (Greenstein and Winitz, 1961). It is known that chelating agents such as EDTA and citric acid can play a role as excitants (Curtis and Crawford, 1969). Thus the increase in seizures with administration of L-cysteine may result from chelation of bivalent ions especially calcium.

On the other hand, it is known that increased $\mathrm{Ca}^{\mathrm{H}}$ concentrations in CSF have strong anticonvulsant effects in cats (Zuckermann and Glaser, 1973). Similarly release of GABA can be increased through increments in the extracellular concentration of $\mathrm{Ca}+$ in cat cerebral cortex (Kaczmarek and Adey, 1973).

Isethionic acid increases calcium uptake in rat liver mitochondria to a lesser extent than taurine (Dolara, Marino et al., 1973). Moreover, Welty and Read (1964) postulated that the intracellular accumulation of potassium caused by taurine in dog heart slices, might actually be due to isethionic acid converted from taurine. Isethionic acid, however, showed no antiseizure activity in the present studies. We did not investigate cysteic acid, another precursor of taurine, but the role of cysteic acid as a precursor is known to be less than that of hypotaurine. Furthermore, the inhibitory effect of cysteic acid on taurine uptake is known to be weaker than that of hypo taurine (Lähdesmäki and Oja, 1973).

$\beta$-alanine, L-alanine, glycine and L-proline

$\beta$-alanine and glycine and less so, $\mathrm{L}$-proline and $\mathrm{L}$-alanine, are thought to be inhibitory neurotransmitter candidates in the brain or spinal cord (Curtis and Crawford, 1969). $\beta$-alanine inhibits the transport of GABA and of taurine from the CSF of cat, while glycine and L-alanine has no significant effects (Snodgrass and Lorenzo, 1973). The uptake of taurine into rat cortical slices is also inhibited by $\beta$-alanine, but is unaffected by glycine (Kaczmarek and Davison, 1972; Lähdesmäki and Oja, 1973). Snyder, Young et al. (1973) found that the displacement of strychnine binding in the synaptic membrane by glycine and glycine analogs paralleled glycine-like neurophysiological activity. Displacing potency was in the following order: glycine, $\mathrm{L}$ - $\beta$-alanine, taurine, L- $\alpha$-alanine and finally proline. Alanine and glycine have been found in synaptic vesicle from rat cerebral cortex (De Belleroche and Bredford, 1973). The high affinity uptake of glycine in cat spinal cord slices was not inhibited by L-alanine, $\beta$-alanine, GABA or taurine. Conversely, glycine did not inhibit GABA uptake (Balcar and Johnston, 1973). Obata and Yoshida (1973) reported that electrophoretic administration of picrotoxin or bicuculline depressed the inhibitory action of GABA, but not that of glycine; by contrast, strychnine blocked only the action of glycine in cat entopeduncular cells. The same effect of picrotoxin on the actions of GABA and glycine was also exhibited in frog spinal neurones (Barker and Nicoll, 1973). From such studies. Snyder, Young et al. (1973) have asserted that proline should also be considered as a potential central neurotransmitter since it behaved similarly to glutamic and aspartic acids and glycine upon uptake and release.

In the present studies of the four amino acids listed, $\beta$-alanine was the most effective against ouabaininduced seizures. L-alanine and glycine also displayed considerably potent antiseizure activities. L-proline suppressed only clonictonic seizures, but permitted an increase in the incidence of running seizures at high concentrations.

\section{Betaine and L-arginine}

Betaine (glycine betaine) was investigated because of its structural similarity to the inhibitory neurotransmitter candidate glycine. Ar- 
ginine was studied because of its protective effects against hepatic coma, insulin shock and epilepsy in rat, probably through its action upon tissue ammonia levels (Roberge and Charbonneau, 1969). However, betaine and L-arginine had no suppressive effects against ouabain-induced seizures. Moreover, L-arginine caused an increase in the incidence of clonic-tonic seizures at a dose of $1.5 \times 10^{-1} \mathrm{M}$. This aggravation may be due to increases in extra cellular potassium concentration caused by some basic amino acids, including arginine (Alberti et al., 1971).

\section{Comparison with taurine and GABA}

Comparison of the effect of hypotaurine, the most effective compound in this study, and that of taurine or GABA examined previously (Izumi et al., 1973), revealed that taurine is the most potent inhibitor of the occurrence and incidence of ouabain-induced seizures. At a concentration of $9.5 \times 10^{.2} \mathrm{M}$, taurine completely suppressed clonic-tonic and running seizures. Significant suppressive effects were also obtained with $4.75 \times 10^{-1} \mathrm{M}$ taurine. In high doses $\left(1.9 \times 10^{-1} \mathrm{M}\right)$, hypotaurine as well as GABA completely abolished all seizure activity. At low concentrations $\left(9.5 \times 10^{-2} \mathrm{M}\right)$ hypotaurine diminished clonic-tonic seizures better than GABA. On the other hand, running seizures were more clearly suppressed by GABA than by hypotaurine.

The difference of efficacy between GABA and other amino acids tested for running and clonic-tonic seizures deserves some comments. Lähdesmäki and Oja (1973) while investigating the transport sites of taurine at the cell membrane level in rat cortex, postulated that taurine recognizes in the acceptable molecule both strongly ionized electronegative and electropositive ends, separated by at least two carbon atoms. This is the optimal length of the carbon chain in such a molecule. The blocking effects of some structural analogs of taurine upon transport sites of this amino acid were, in decreasing order of effects: hypotaurine, $\beta$-alanine, GABA and finally L-cysteic acid.
Isethionic acid, L-cysteine and glycine displayed no inhibitory property. This order corresponds almost with that of the antiseizure activity recorded in the present studies, except for glycine which was found to be almost as effective against ouabain induced seizures as $\beta$-alanine.

Electrolytes are intimately related to seizure phenomena: ouabain increases the extracellular concentration of potassium, probably contributing to the seizure inducing mechanism by its inhibitory action upon $\mathrm{Na}+\mathrm{K}+-\mathrm{ATP}$ ase. Perfusion of the brain with high concentrations of potassium can cause epileptic seizures (Zuckermann and Glaser, 1968). Conversely, a high calcium concentration in the cerebrospinal fluid can have anticonvulsant effects in cat (Zuckermann and Glaser, 1973). Krnjevic and Lisiewicz (1972) reported that $\mathrm{Ca}^{2}+$ injected into spinal motoneurones caused a reduction in excitability and a fall in membrane resistance and that the most common change in membrane potential was a hyper-polarization. They postulated that the increase in permeability caused by $\mathrm{Ca}+$ would explain the $\mathrm{Ca}+$ dependent release of transmitter (Kasczmarek and Adey, 1973; Rubin, 1970). Recent reports revealed that ATP-dependent calcium uptake, in conditions of high external calcium $(10 \mathrm{mM})$, is increased significantly by taurine and isethionic acid (Dolara, Marino et al., 1973) and that taurine increases the affinity of some cell structures for calcium (Dolara, Agresti et al., 1973 b). Huxtable and Bressler (1973), with rat muscle in vitro, also observed that calcium oxalate uptake in sarcoplasmic reticulum was increased with taurine and that taurine slowed the rate of loss of calcium and decrease in ATP'ase activities of sarcoplasmic reticulum caused by phospholipase C. However isethionic acid and cysteine showed no such effects.

Data listed here clearly indicates the possible correlation between calcium, taurine and membrane stability or excitability. Moreover, as mentioned above, hypotaurine, $\beta$-alanine and glycine have structural similarities to taurine. Finally hypotaurine and $\beta$-alanine block the transport sites of taurine. Hence the antiseizure activity of some of these taurine analogs might relate to the mediating role of calcium or at least to that of some membrane stabilizing ions. However, isethionic acid which showed no suppressive effect against ouabain-induced seizures can also favor calcium accumulation (Dolara, Marino et al., 1973), thus the calcium mobilization theory cannot be the only explanation of this activity. Because of this, Barbeau and Donaldson (1974) favor a role for taurine as stabilizer of membrane excitability rather than as a neurotransmitter. Huxtable and Bressler (1973) also suggest that taurine may function as a membrane stabilizer.

Finally it should be recalled that no amino acids examined in the present series were more effective against ouabain-induced seizures than taurine, previously tested under the same conditions. Even with effective amino acids, running and leaping seizures were difficult to suppress compared with other types of seizures.

\section{REFERENCES}

ALBERTI, K. G., SHAHRIARI, A. A., LEVINE, H. D., and LAULER, D. P. (1971). Reversal of ouabain-induced arrhythmias in the dog by intravenous arginine hydrochloride. Cardiovascular Research, 5, 226-235.

BALCAR, V. J., and JOHNSTON, A. R. (1973). High affinity uptake of transmitters: Studies on the uptake of L-aspartate, GABA, L-glutamate and glycine in cat spinal cord. Journal of Neurochemistry, 20, 529-539.

BARBEAU, A., and DONALDSON, J. (1974). Zinc, taurine and epilepsy. Archives of Neurology, 30, 52-58.

BARKER, J. L., and NICOLL, R. A. (1973). The pharmacology and ionic dependency of amino acid responses in the frog spinal cord. Journal of Physiology, 228, 259-277.

BARKULIS, S. S., GEIGER, A., KAWAKITA, Y., and AGUILAR, V. (1960). A study on the incorporation of ${ }^{14} \mathrm{C}$ derived from glucose into the free amino acids of the brain cortex. Journal of Neurochemistry, 5, 339-348.

BOINEAU, F. (1973). Effect of penicillamine and penicillin on calcium and magnesium levels of escherichia coli $\mathrm{K}_{12}$. Bordeaux Medical, 6, 1115-1127, (from Chem. Abst. 79 (1973) $38882 \mathrm{~h}$ ). 
CURTIS, D. R., and CRAWFORD, J. M. (1969). Central synaptic transmission - Microelectrophoretic studies. Annual Revue of Pharmacology, 9, 209-240.

DE BELLEROCHE, J. S., and BREDFORD, H. F. (1973). Amino acids in synaptic vesicles from mammalian cerebral cortex: A reappraisal. Journal of Neurochemistry, 21, 441-451.

DOLARA, P. , MARINO, P., and BUFFONI, F. (1973). Effect of 2-amino ethanesulphonic acid (taurine) and 2-hydroxyethane sulphonic acid (isethionic acid) on calcium transport by rat liver mitochondria. Biochemical Pharmacology, 22, 2085-2094.

DOLARA, P., AGRESTI, A., GIOTTI, A., and PASQUINI, G. (1973). Effect of taurine on calcium kinetics of guinea-pig heart. European Journal of Pharmacology, 24, 352-358.

DONALDSON, J., ST-PIERRE, T., MINNICH, J., and BARBEAU, A. (1971). Seizures in rats associated with divalent cation inhibition of $\mathrm{Na}+-\mathrm{K}+-\mathrm{ATP}$ 'ase. Canadian Journal of Biochemistry, 49, 1217-1224.

DUNN, A., and GIUDETTA, A. (1971). A long term effect of electroconvulsive shock on the metabolism of glucose in mouse brain. Brain Research, 27, 418-421.

EHINGER, B., and FALCK, B. (1971). Autoradiography of some suspected neurotransmitter substances GABA, glycine, glutamic acid, histamine, dopamine and L-DOPA. Brain Research, 33, 157-172.

EHINGER, B. (1972). Cellular location of uptake of some amino acids into the rabbit retina. Brain Research, 46, 297-311.

GOLDSTEIN, A. (1964). Biostatistics. The Macmillan Co., New York, p. 51.

GREENSTEIN, J. P., and WINITZ, M. (1961). Metal and salt combinations with amino acids. In: Chemistry of the amino acids, John Wiley and Sons, Inc., New York - London, Vol. 1, p. 569.

HAHASHI, T. (1972). In: Comprehensive management of epilepsy in infancy, childhood and adolescence. (Livingston, S., ed.), Thomas, C. C., Springfield, Illinois, pp. 313-314.

HUXTABLE, L., and BRESSLER, B. (1973). Effect of taurine on muscle intercellular membrane. Biochem. Biophys. Acta., 323, 573-583.

IVERSEN, L. L., and SCHON, F. E. (1973). The use of autoradiographic techniques for the identification and mapping of transmitter - specific neurons in CNS. In: "New concepts in neurotransmitter regulation"
(A. J. Mandell, Ed.), Plenum Press, New York, pp. 153-194.

IZUMI, K., DONALDSON, J., MINNICH, J. J., and BARBEAU, A. (1973). Ouabaininduced seizures in rats: Suppressive effects of taurine and $\gamma$-aminobutyric acid. Canadian Journal of Physiology and Pharmacology, 51, 885-889.

JONES, D. A., and McILWAIN, H. (1971). Amino acid distribution and incorporation into protein in isolated electricallystimulated cerebral tissues. Journal of Neurochemistry, 18, 41-58.

KACZMAREK, L. K., and DAVISON, A. N. (1972). Uptake and release of taurine from rat brain slices. Journal of Neurochemistry, 19, 2355-2362.

KACZMAREK, L. K., and ADEY, W. R. (1973). The efflux of ${ }^{45} \mathrm{C}^{2+}$ and $\left({ }^{3} \mathrm{H}\right) \gamma$ aminobutyric acid from : cat cerebral cortex. Brain Research, 63, 331-342.

KOYAMA, I. (1972). Amino acids in the cobalt-induced epileptogenic and non epileptogenic cat's cortex. Canadian Journal of Physiology and Pharmacology, 50, 740-752.

KRNJEVIC, K., and LISIEWICZ, A. (1972). Injections of calcium ions into spinal motoneurones. Journal of Physiology, 225, 363-390.

LÄHDESMÄKI, P., and OJA, S. S. (1973). On the mechanism of taurine transport at brain cell membranes. Journal of Neurochemistry, 20, 1411-1417.

LITCHFIELD, J. T., and WILCOXON, F. (1949). A simplified method of evaluating dose-effect experiments. Journal of Pharmacology and Experimental Therapeutics, 96, 99-113.

NAHORSKI, S. R., ROBERTS, D. J., and STEWART, G. G. (1970). Some neurochemical aspects of pentamethylenetetrazole convulsive activity in rat brain. Journal of Neurochemistry, 17, 621-631.

OBATA, K., and YOSHIDA, M. (1973). Caudate-evoked inhibition and actions of GABA and other substances on cat pallidal neurones. Brain Research, 64, 455-459.

OJA, S. S., KARVONEN, M. L., and LÄHDESMÄKI, P. (1973). Biosynthesis of taurine and enhancement of decarboxylation of cysteine sulphinate and glutamate by the electrical stimulation of rat brain slices. Brain Research, 55, 173-178.

ORREGO, F., and LIPMANN, F. (1967). Protein synthesis in brain slices. Effects of electrical stimulation and acidic amino acids. Journal of Biological Chemistry, 242, 665-671.
PERRY, T. L., and HANSEN, S. (1973). Quantification of free amino compounds of rat brain: Identification of hypotaurine. Journal of Neurochemistry, 21, 1009-1011.

REYNOLDS, A. P., and GALLAGHER, B. B. (1973). The effect of hexafluorodiethyl ether (Flurothyl) on the metabolism of rat brain amino acids labelled by $\left(\mathrm{U}-{ }^{14} \mathrm{C}\right)$ glucose. Life Science, 13, 87-95.

ROBERGE, A., and CHARBONNEAU, R. (1969). Protective effects of arginine against hepatic coma, insulin shock and epilepsy. Life Science, 8, 369-377.

RUBIN, P. (1970). The role of calcium in the release of neural transmitter substances and hormones. Pharmacology Revue, 22, 389-428.

SNODGRASS, S. R., and LORENZO, A. V. (1973). Transport of GABA from the perfused ventricular system of the cat. Journal of Neurochemistry, 20, 761-769.

SNYDER, S. H., YOUNG, A. B., BENNETT, J. P., and MULDER, A. H. (1973). Synaptic biochemistry of amino acids. Federation Proceedings, 32, 2039-2047.

SNYDER, S. H., YAMAMURA, H. I., PERT, C. B., LOGAN, W. J., and BENNETT, J. P. (1973). Neuronal uptake of neurotransmitters and their precursors Studies with "transmitter" amino acids and choline. In: (Mandell, A. J., ed.). New concepts in neurotransmitter regulation. Plenum Press, New York - London, pp. 195-222.

VAN GELDER, N. M., SHERWIN, A. L., and RASMUSSEN, T. (1972). Amino acid content of epileptogenic human brain: Focal versus surrounding regions. Brain Research, 40, 385-393.

VAN GELDER, N. M. (1972). Antagonism by taurine of cobalt induced epilepsy in cat and mouse. Brain Research, 47, 157-165.

WELTY, J. D., and READ, W. O. (1964). Studies on some cardiac effects of taurine. Journal of Pharmacology and Experimental Therapeutics, 144, 110-115.

WINER, B. J. (1971). Statistical principles in experimental design. 2nd Edition, McGraw-Hill Book Co., New York.

ZUCKERMANN, E. C., and GLASER, G. H. (1973). Anticonvulsive action of increased calcium concentration in cerebrospinal fluid. Archives of Neurology, 29, 245-252.

ZUCKERMANN, E. C., and GLASER, G. H. (1968). Hippocampal epileptic activity induced by localized ventricular perfusion with high potassium cerebrospinal fluid. Experimental Neurology, 20, 87-110. 